Check for updates

The BMJ

Cite this as: BMJ2020;370:m3391 http://dx.doi.org/10.1136/bmj.m3391 Published: 02 September 2020

\section{Covid-19: Pregnant women with virus are more likely to need intensive care, study finds}

\section{Elisabeth Mahase}

Pregnant women in hospital with covid-19 are less likely to show symptoms than non-pregnant women of similar age but may have an increased risk of admission to intensive care, a study published in The BMJ has found.

Researchers from the UK, the US, Spain, China, Switzerland, and the Netherlands found that pregnant women with covid-19 were also more likely to have a preterm birth and that their newborns were more likely to be admitted to a neonatal unit. Other factors that increased the risk of severe covid-19 in these women included being older, being overweight, and having pre-existing medical conditions such as hypertension or diabetes.

The team, partially funded by the World Health Organization, analysed 77 cohort studies reporting the rates, clinical manifestations, risk factors, and maternal and perinatal outcomes in 11432 pregnant and recently pregnant women with suspected or confirmed covid-19.

Overall, they found that $10 \%$ ( $95 \%$ confidence interval $7 \%$ to $14 \%$ ) of pregnant and recently pregnant women attending or admitted to hospital for any reason had a diagnosis of suspected or confirmed covid-19. The most commonly reported symptoms were fever (40\%) and cough (39\%), and in total 73 pregnant women with covid-19 (0.1\%; 26 studies; 11580 women) died from any cause.

When compared with non-pregnant women of reproductive age, the pregnant and recently pregnant women with covid-19 were less likely to report symptoms of fever (odds ratio 0.43 ( 0.22 to 0.85 ); $\mathrm{I}^{2}=74 \%$; 5 studies; 80521 women) and myalgia (0.48 (0.45 to 0.51); $I^{2}=0 \%$; 3 studies; 80409 women).

However, they were more likely to need admission to an intensive care unit (1.62 (1.33 to 1.96)) and invasive ventilation (1.88 (1.36 to 2.60$)$ ).

\section{Risk factors}

Risk factors associated with the odds of severe covid-19 in pregnancy were increased maternal age (1.78 (1.25 to 2.55$)$ ), high body mass index (2.38 (1.67 to 3.39); $\mathrm{I}^{2}=0 \%$ ), chronic hypertension (2.0 (1.14 to 3.48)), and pre-existing diabetes (2.51 (1.31 to 4.80)).

Pre-existing maternal comorbidity was also a risk factor for admission to intensive care (4.21 (1.06 to 16.72)) and invasive ventilation (4.48 (1.40 to 14.37)). In addition, pregnant women with covid-19 showed higher odds of any preterm birth (3.01 (1.16 to 7.85)), and their babies showed increased odds of admission to a neonatal unit (3.13 (2.05 to 4.78)).

The authors concluded that healthcare professionals needed to be aware that pregnant women with covid-19 might need access to intensive care and specialist baby care facilities and suggested that mothers with pre-existing comorbidities should be considered to be a high risk group for covid-19, along with those who were obese or older.

The team noted some study limitations, including differences between the included studies in terms of size, design, and their definitions of symptoms, tests, and outcomes.

Allotey J, Stallings E, Bonet M, etal. Clinical manifestations, risk factors, and maternal and perinatal outcomes of coronavirus disease 2019 in pregnancy: living systematic review and meta-analysis. BMJ2020;370:m3320. https://www.bmj.com/content/370/bmj.m3320.

This article is made freely available for use in accordance with BMJ's website terms and conditions for the duration of the covid-19 pandemic or until otherwise determined by BMJ. You may use, download and print the article for any lawful, non-commercial purpose (including text and data mining) provided that all copyright notices and trade marks are retained. 